\title{
PENEGAKAN OTONOMI PASIEN MELALUI PERSETUJUAN TINDAKAN MEDIS (INFORMED CONSENT)
}

\author{
Dionisius Felenditi
}

FIP UNIMA/Dosen Luar Biasa Fakultas Kedokteran Unsrat e-mail: paai_manado@yahoo.com

\begin{abstract}
Informed consent is the voluntary consent given by the patient for medical treatment, after he/she has obtained all the necessary information about the possible risks of the treatment. Informed consent is done upon the principle of autonomy, beneficence, and nonmaleficence. This is based on the principle of patient dignity wherein the personal autonomy and integrity of the patient is protected and respected. If the patient is incompetent, the consent will be given by the family, the legal proxy, or the guardian. If the family or the guardian is present but they are also incompetent, then the medical staff themselves must make a decision to determine the appropriate medical treatment in accordance with the patient's condition. Informed consent is especially needed in extraordinary means. Albeit, for a patient in critical condition or in an emergency wherein the medical treatment must be done immediately as a life-saving procedure, proxy consent is not needed.
\end{abstract}

Keywords: informed consent/refusal, autonomy, competence, extraordinary means

\begin{abstract}
Abstrak: Informed consent ialah persetujuan bebas yang diberikan oleh pasien terhadap suatu tindakan medis, setelah ia memperoleh semua informasi yang penting mengenai sifat serta konsekuensi tindakan tersebut. Informed consent dibuat berdasarkan prinsip autonomi, beneficentia dan nonmaleficentia, yang berakar pada martabat manusia di mana otonomi dan integritas pribadi pasien dilindungi dan dihormati. Jika pasien tidak kompeten, maka persetujuan diberikan oleh keluarga atau wali sah. Jika keluarga/wali hadir tetapi tidak kompeten juga, maka tenaga medis harus memutuskan sendiri untuk melakukan tindakan medis tertentu sesuai keadaan pasien. Informed consent terutama dibutuhkan dalam kasus-kasus luar biasa (exraordinary means). Namun untuk pasien kritis atau darurat yang harus segera diambil tindakan medis untuk menyelamatkannya, proxy consent tidak dibutuhkan.
\end{abstract}

Kata kunci : persetujuan/penolakan, otonomi, kompetensi, sarana luar biasa

The Oxford English Dictionary, mendefinisikan istilah "consent" sebagai "voluntary agreement to, or acquiescence in, what another proposes or desires; compliance, concurrence, permission". 4 Dengan informed consent dimaksudkan persetujuan bebas yang diberikan oleh pasien terhadap suatu tindakan medis, setelah ia memperoleh semua informasi penting me- ngenai sifat serta konsekuensi tindakan tersebut. Prinsip informed consent berakar pada martabat manusia di mana otonomi dan integritas pribadi pasien harus dilindungi. Integritas manusia menuntut bahwa setiap orang bertindak menurut apa yang diketahuinya dan berdasarkan pilihan bebasnya. Pilihan sedemikian secara personal bersumber dari dalam diri sendiri, 
dan bukan dari dorongan internal buta atau karena tekanan eksternal. ${ }^{3,4}$

Prinsip informed consent merupakan hak dan kewajiban setiap individu yang kompeten untuk meningkatkan kehidupan spiritualnya dan kesejahteraan jasmaninya melalui persetujuan bebasnya, atau dengan menolak memberi persetujuan atas tindakan medis tertentu berdasarkan pengetahuan yang cukup tentang keuntungan, kerugian dan resiko yang terkait. Bagi individu yang tidak kompeten, hak dan kewajiban ini harus diinterpretasi oleh penjamin individu tersebut (pasien) yang sah sesuai pengetahuannya atau keinginannya yang rasional. ${ }^{6}$

\section{Informed consent dan prinsip otonomi}

Walaupun moralitas tindakan dari tenaga medis sangat dipengaruhi oleh etos, kode-kode etik dan keyakinan agama yang dianutnya, namun moralitas tindakannya terutama ditentukan oleh keputusan hati nuraninya. Dengan keputusan hati nurani dimaksudkan keputusan yang bersumber dalam pusat kepribadian yang mewajibkannya untuk bertindak pada saat itu demi kepentingan terbaik pasien. Dalam hubungan ini muncul apa yang biasa dikenal dengan "otonomi moral" dan "otonomi klinis".

Etika mengajarkan bahwa setiap pribadi mempunyai "otonomi moral", artinya ia mempunyai hak dan kewajiban untuk menentukan sendiri tindakantindakannya (self-determination) dan mempertanggungjawabkannya. Otonomi menekankan kreativitas dan produktivitas, serta menolak konformitas. Otonomi menuntut bahwa kita sendiri menentukan siapakah kita ini dan bersedia bertanggung jawab atas pilihan itu. Selain itu tenaga medis juga memiliki "otonomi klinis", yaitu hak dan kewajiban tenaga medis untuk bertanggung jawab dalam pengambilan keputusan klinis yang mempengaruhi kesehatan pasiennya. Pihak lain mana pun tidak boleh memaksakan kehendak atas diri tenaga medis. Tenaga medis dalam banyak hal wajib mendengarkan pendapat pihak-pihak lain, tetapi tidak boleh bertindak sematamata karena terpaksa mengikuti pendapat lain tersebut. Keputusan terakhir berada dalam tanggung jawab dokter. Oleh karena otonomi moral yang dimiliki pasien, maka dokter berkewajiban memberikan informasi untuk mendapatkan persetujuan, namun tidak boleh memaksakan persetujuan tersebut. ${ }^{1,2,10}$

"Otonomi klinis" tidak berarti pula hak untuk bertindak gegabah dan meremehkan pendapat tenaga medis lain terutama ahli-ahli yang berkompeten. Kebebasan hati nurani hanya pantas diakui apabila orang sudah sungguh-sungguh berusaha sebaik mungkin untuk mencari kebenaran. Menurut Immanuel Kant (17241804) dan kaum deontolog, menghormati sesama berarti membiarkannya sebagai individu bebas untuk membuat pertimbangan sendiri dan bertindak sesuai pilihannya (dalam batas-batas moral tertentu). Hormat sedemikian dituntut semata-mata demi orang lain sebagai individu yang memiliki integritas moral yang dapat menentukan sikap dan tujuannya sendiri. Hormat ini muncul dari kesadaran bahwa semua orang memiliki nilai diri yang tak bersyarat dan tujuan dalam dirinya sendiri. Intersubyektivitas harus dijiwai sikap saling menghormati. Menurut John Stuart Mill (18061873), pilihan dan tindakan pelaku otonom tidak boleh dibatasi orang lain selama tidak merugikan orang lain dan/atau dirinya sendiri. Meskipun demikian prinsip selfdetermination ini sering sulit diterapkan dalam klinik karena problem penyakit dan penderitaan yang sering sudah sangat menurunkan kemampuan pasien dan/atau keluarganya untuk berpikir dan mengambil keputusan secara rasional. Namun karena seringnya terjadi praktek medis yang 
melanggar prinsip ini, maka kode etik profesi mengungkapkan pentingnya hormat akan otonomi ini. ${ }^{2}$

Dalam Kode Nuremberg dikatakan:"This voluntary consent of the human subject is absolutely essential. This means that the person involved should have the legal capacity to give consent; should be so situated as to be able to exercise free power of choice, without the intervention of any element of force, fraud, deceit, duress, over-reaching, or other ulterior form of constraint or coercion; and should have sufficient knowledge and comprehension of the subject matter involved as to enable him to make an understanding and enlightened decision. This later element requires that before the acceptance of an affirmative decision by the experimental subject there should be made known to him the nature, duration, and purpose of the experiment; the methods and means by which it is to be conducted; all inconveniences and hazards reasonably to be expected; and the effects upon his health or person which may possibly come from his participation in the experiment" (Nuremberg Code, Rule 1). ${ }^{1}$

Bagian akhir kode ini mengungkapkan keharusan untuk memperoleh informed consent dari setiap orang yang mau diikutsertakan dalam sebuah eksperimen. Dalam hukum Anglo-Amerika misalnya, ajaran tentang "informed consent" ini lambat laun muncul akibat praktek medis menyangkut campur tangan dokter atas tubuh pasien tanpa persetujuannya. Dewasa ini semua kode etik medis dan penelitian, mengharuskan dokter untuk memperoleh informed consent dari pasien-pasiennya sebelum melakukan tindakan medis atau prosedur pemeriksaan tertentu. ${ }^{1,10}$

Fungsi-fungsi informed consent adalah melindungi dan meningkatkan otonomi pasien, melindungi pasien dan subyek peserta penelitian, mencegah tindakan manipulatif dan pemaksaan, meningkatkan sikap mawas diri dari tim medis, meningkatkan pengambilan keputusan rasional, dan melibatkan publik dalam pengembangan otonomi sebagai nilai sosial dan kontrol terhadap penelitian biomedis. ${ }^{1,10}$

Fungsi-fungsi ini dibuat berdasarkan beberapa prinsip moral, yaitu prinsip autonomi, beneficentia, nonmaleficentia, dan utilitas. Prinsip autonomi adalah melindungi dan meningkatkan otonomi individu. Hubungan baik antara dokter dan pasien akan mencegah terjadinya ketidaktahuan yang justru menghambat otonomi pasien dan/atau keluarga untuk memutuskan, ketidaktahuan mana dapat berasal dari kekurangan informasi atau karena kurang paham. Prinsip beneficentia adalah melindungi pasien serta subyek peserta penelitian, sedangkan prinsip nonmaleficentia mencegah timbulnya kerugian atas pasien, terutama pasien tidak sadar, anak-anak, mental terbelakang, dan sebagainya. Dalam hal ini, orang tua atau keluarga pasien atau orang lain yang secara legal dapat diterima untuk mewakili pasien, dapat memberi persetujuan. Prinsip utilitas adalah meningkatkan sikap mawas diri tim medis dalam melakukan tindakan yang menguntungkan setiap orang dalam masyarakat, termasuk tenaga kesehatan sendiri, pasien-pasien dan para peneliti sehingga dapat tetap terbina sikap saling percaya.

\section{Informed consent dan extraordinary means}

Informed consent harus diperoleh dari pasien dengan kasus medis berat dan beresiko, dimana bila dilakukan prosedur medis tertentu tidak dapat dipastikan akan memberikan hasil positif. Dengan kata lain informed consent harus diperoleh dari pasien bila ditempuh tindakan medis sebagai extraordinary means. Menurut etika-moral extraordinary means yaitu semua tindakan yang mengakibatkan penderitaan atau pembiayaan yang melampaui batas normal dalam situasi lingkungan 
tertentu. Yang termasuk di sini adalah tindakan-tindakan yang mungkin mengubah kepribadian, menghalangi hubungan pasien dengan sanak keluarganya, mengurangi daya manusiawi, atau tidak memberi harapan besar akan manfaatnya. Pasien tidak harus meminta, juga dokter tidak harus menyediakan perawatan seperti itu, kecuali dalam keadaan tertentu, misalnya pasien masih membutuhkan waktu lebih banyak untuk menyelesaikan suatu tugas sosial, atau demi persiapan rohani dan keagamaan menjelang kematiannya. Drew dan Ford berpendapat bahwa extraordinary means adalah obat-obatan, perawatan, dan operasi yang tidak dapat diperoleh, digunakan, atau dilakukan tanpa berefek seperti penderitaan atau gangguan lainnya Dan bila diterapkan, tidak akan memberikan harapan wajar akan kesembuhan. Dalam bidang medis, tindakan extraordinary means meliputi penelitian dan percobaan yang efektivitasnya belum jelas atau bahkan mempunyai angka mortalitas tinggi. Juga tindakan yang mengandung ketidakseimbangan antara kesakitan, kerusakan anggota badan, atau kerugian psikologis, dengan manfaat yang dapat diperkirakan, baik dalam jangka pendek maupun panjang, atau dengan biaya yang terlampau tinggi. ${ }^{5,9}$

Berkenaan dengan tindakan medis yang dipandang sebagai extraordinary means, dokter berkewajiban untuk memberi informasi dan meminta persetujuan dari pasien dan/atau keluarga sambil memperhatikan kompetensinya. Sikap yang mengabaikan prinsip informed consent ini berlatar belakang pada sikap paternalistis dokter yang dewasa ini semakin dipersoalkan karena semakin berkembangnya kesadaran akan otonomi pasien dan/atau keluarga yang harus dihormati. Yang dimaksud dengan paternalisme yaitu setiap tingkah laku yang memperlakukan seseorang seolah-olah dia seorang anak. Dalam konteks etika, kata paternalisme biasanya dipakai untuk me- nunjukkan setiap tindakan yang membatasi kebebasan seseorang tanpa persetujuannya dengan maksud atau mencegah kerugian bagi dia atau melakukan sesuatu yang baik, yang tidak dapat diperolehnya dengan cara lain. Memang sikap paternalistis tidak selalu salah karena sikap ini juga berdasar pada prinsip beneficentia. Namun sikap ini salah jika dokter berhadapan dengan pasien yang otonom yang berhak memperoleh informasi yang benar dan jelas mengenai keadaan penyakitnya serta tindakan medis yang akan dijalani.

Terhadap tindakan medis yang dikategorikan extraordinary means, pasien tidak diharuskan untuk memberi persetujuan. Bila persetujuan diberikan atas dasar "doctor knows the best", yang berarti persetujuan pasien merupakan ungkapan serah diri secara total kepada dokter atas dasar kepercayaan bahwa dokter mengetahui yang terbaik, maka persetujuan pasien tersebut tidak sah. Dan sehubungan dengan tindakan medis tambahan atau lanjutan yang termasuk extraordinary, pasien dan/atau keluarga harus dimintakan persetujuan atas tindakan tersebut, baik yang dapat membantu proses penyembuhan atau hanya merupakan tindakan medis yang tidak bermanfaat. Bila merupakan tindakan medis yang tidak bermanfaat, maka tidak perlu dilakukan, dan bila sudah dilakukan tidak perlu dilanjutkan. Dalam "Deklarasi tentang Euthanasia" (1980) dikatakan: "If other remedies are lacking, it is permissible with the consent of the sick person, to use the most recent medical techniques, even if there are not yet fully tested and are not free of risk. The sick person who agrees to them can even give an example thereby, of generous service to the human race". Dalam hal ini tindakan medis yang agresif harus dibedakan dari tindakan yang tidak dibutuhkan (unnecessary). Bila beban dari tindakan pertahanan kehidupan seperti penggunaan respirator, pemberian oksigen, kemoterapi 
dan lain-lain jauh dari harapan sembuh, maka tidak ada kewajiban untuk melanjutkannya. 6,9

\section{Unsur-Unsur yang tercakup dalam in- formed consent}

Kode etik kedokteran dan penelitian menekankan bahwa persetujuan harus muncul dari kemauan bebas (voluntarium) pasien, dan harus merupakan jawaban atas informasi yang sesuai dengan keadaan sebenarnya. Informed consent ini harus benar dan sesuai dengan pemahaman pasien dan petugas medis. Persetujuan ini harus muncul dari keputusan bebas orang yang kompeten. Unsur-unsur informed consent yang dimaksud yaitu : kompetensi, penyampaian informasi, pemahaman informasi, dan kebebasan serta persetujuan. ${ }^{1,8}$

Kompetensi (competence to consent, competentia = wewenang, kecakapan, kesanggupan) mungkin lebih cocok disebutkan sebagai presuposisi daripada sebagai unsur informed consent. Dalam konteks ini, kompetensi mengacu ke suatu prekondisi untuk bertindak secara sukarela karena memahami pentingnya informasi. Kompetensi ialah kesanggupan pasien untuk mengambil keputusan tentang pengobatan dengan mempertimbangkan semua faktor yang relevan. Seorang pasien adalah kompeten jika bisa mengambil keputusan atas dasar alasan rasional. Ia harus dapat memahami prosedur, mem-pertimbangkan resiko dan manfaat, serta dapat mengambil keputusan sesuai dengan pengetahuannya dan nilai-nilai serta tujuan yang hendak dicapai.Sebaliknya tidak kompeten (incompetent) yaitu bila tidak dapat memahami prosedur dan tindakan medis. Umumnya yang tidak kompeten adalah anak-anak, pengidap penyakit jiwa atau depresi, dan pasien yang tak sadar, bingung, atau panik. ${ }^{1,10}$

Terdapat banyak kondisi eksternal dan internal yang dapat membatasi tindak- an bebas pasien. Oleh karena itu sebelum melakukan tindakan medis tertentu, tim medis harus memeriksa apakah pasien tersebut kompeten atau tidak kompeten untuk dimintakan persetujuan-nya. Pasien kompeten adalah pasien dewasa yang mampu memahami keadaan penyakitnya, resiko dan alternatif tindakan medis, dan mampu menerima informasi serta memilih dengan bebas tindakan medis yang ditawarkan. Bila pasien tidak kompeten, maka persetujuan dapat diminta dari keluarga/wali. Bila keluarga/wali tidak ada, atau bila hadir tetapi tidak kompeten, maka tim medis harus memutuskan sendiri apakah dapat dilakukan tindakan/terapi tersebut sesuai situasi pasien. Terdapat tiga standar kompetensi pasien dan/atau keluarga untuk mengambil keputusan: 1) Kemampuan untuk mengambil keputusan atas dasar pertimbangan rasional (rational reason). Bila dihadapkan pada beberapa pilihan, orang tersebut harus dapat memilih suatu alternatif. 2) Kemampuan untuk memberi alasan bagi pilihannya. 3) Pilihan itu harus logik. Dengan kata lain, kompetensi adalah kemampuan mencapai hasil yang dapat dipertanggungjawabkan melalui suatu keputusan. Dalam konteks biomedik, standar-standar ini mengandung pengertian bahwa seorang pasien dan/atau keluarganya harus mampu memahami suatu terapi/ tindakan medis atau prosedur medis tertentu, serta harus mampu mempertimbangkan resiko dan keuntungan yang dapat dicapai. Berdasarkan pemahaman ini pasien dan/atau keluarga dapat menyatakan pesetujuannya atau menolak. 1,8

Dalam hal penyampaian informasi (disclosure of information), dibutuhkan kondisi yang memungkinkan agar seseorang dapat memperoleh informasi yang cukup untuk mengambil keputusan (informed choice). Hal-hal yang perlu diketahui oleh pasien dan/atau keluarganya adalah tindakan medis yang hendak dilaku- 
kan, tindakan medis lain yang tersedia, antisipasi resiko dan efek positifnya. ${ }^{1,10}$

Standar penyampaian informasi dapat berupa standar praktek profesi medis, standar rata-rata yang ingin diketahui oleh pasien berakal sehat, dan standar subyektif. Dalam standar praktek profesi medis (the professional practice standard) penyampaian informasi yang tepat ditentukan oleh praktek medis yang sudah biasa dilakukan. Berdasarkan standar rata-rata yang ingin diketahui oleh pasien berakal sehat (the reasonable person standard) untuk menyampaikan informasi harus diperhatikan apakah pasien dapat memahami informasi tersebut. Ketepatan menerima informasi dapat diukur dengan kemampuan pasien dan/ atau keluarga untuk dapat memahami juga efek negatif dari keputusannya bila mengikuti prosedur medis tertentu. Untuk itu dibutuhkan kondisi tertentu yang dapat membantu mengetahui kompetensi di atas yaitu: semua materi yang penting untuk mengambil keputusan harus disampaikan, pengetahuan tentang efek negatif misalnya cacat tubuh dan kematian, mampu memahami dan menentukan sikap, dan penyampaian informasi didasarkan pada relasi kepercayaan. Walaupun demikian masih terdapat kesulitan lain lagi, yaitu bagaimana memahami keinginan pasien yang tidak kompeten di mana persetujuan diberikan oleh keluarga/wali yang ber-tanggungjawab atas namanya. Selain itu apakah informasi yang diperoleh benar-benar digunakan sebagai dasar untuk mengambil keputusan. Dewasa ini dalam yurisprudensi pengadilan di Amerika Serikat lebih banyak menggunakan standar di atas. 1,10 Standar subyektif (the subjective standard) memperhatikan kebutuhan khusus pasien dengan penyakit tertentu. Dalam hal ini dokter harus menganalisis latar belakang penyakit yang ingin diketahui pasien. Yang menjadi masalah apakah mungkin bagi seorang dokter untuk melayani setiap pasien dengan memberikan informasi tentang keadaan penyakitnya sehingga pasien tersebut telah dipersiapkan dengan baik untuk memberikan pernyataan persetujuannya. Karena kesulitan ini maka standar pemberian informasi yang cocok adalah moralitas yang berdasar pada hormat akan otonomi pasien sambil tetap memperhatikan situasi khusus pasien. Keputusan terbaik harus merupakan gabungan ketiga standar di atas dengan prinsip: "Semua yang dibutuhkan oleh pribadi berakal sehat untuk mengambil keputusan harus disampaikan, dan bersedia memberi jawaban yang benar atas setiap pertanyaan pasien. Namun tidaklah benar mempertahankan otonomi pasien bila ada kriteria yang kuat untuk melanggarnya. Bila pasien dan/atau keluarga tidak memiliki pengertian yang tepat dan benar untuk mengambil keputusan, maka tidak diperlukan informed consent. Informed consent juga tidak dibutuhkan pada keadaan pasien kritis atau darurat yang membutuhkan tindakan medis secara cepat dan tepat sesuai kemampuan tenaga medis dan peralatan medis yang tersedia. Dalam situasi seperti ini dokter memutuskan sendiri untuk melakukan yang terbaik demi kepentingan terbaik pasien, dan hal ini dilakukan atas dasar prinsip beneficentia. ${ }^{1,6}$

Pemahaman informasi (comprehension of information)

Bila pemberian informasi tidak lengkap, maka akan terdapat banyak kondisi yang dapat membatasi pengertian pasien untuk menyatakan persetujuannya. Keadaan ini bisa disebabkan baik oleh pihak informan yang tidak memberi informasi yang jelas, atau pihak penerima informasi yang tidak memahami bahasa dokter. Penerimaan informasi dari pihak pasien juga dipengaruhi oleh kesediaan menerima kebenaran informasi atau tidak. Tugas tenaga medis tidak hanya memahami, tetapi juga meng- 
hargai sikap pasiennya, karena pasien yang telah memahami informasi dokter tidak selalu mau memberikan persetujuannya. Bila dijumpai orang yang tidak dapat bertanggung jawab, maka perawatan dapat saja dilaksanakan sekalipun mungkin tidak sesuai dengan keinginan pasien.

\section{Kebebasan dan persetujuan (voluntary consent).}

Kebebasan di sini berarti bahwa seseorang dapat mengambil keputusan tanpa paksaan atau pengaruh lain yang menekan, baik berupa kekerasan, ancaman, atau manipulasi. Dokter yang mengancam akan menghentikan pengobatan bila pasien tidak menuruti nasihatnya berarti dokter tersebut menjalankan paksaan dan mengabaikan kebebasan pasien. Narapidana yang dijanjikan remisi bila bersedia menyumbangkan sebuah ginjalnya kepada yang membutuhkan transplantasi berarti tawaran ini juga mengurangi kebebasan narapidana tersebut. Walaupun demikian absensi pengaruh luar saja tidak berarti bahwa pasien dapat mengambil keputusan dengan kebebasan penuh. Begitu pula sebaliknya informasi yang diberikan tidak berarti bahwa dokter memaksakan kehendaknya kepada pasien atau keluarganya. Perlu disadari bahwa bebas murni dari pengaruh luar merupakan hal yang ideal tetapi sekaligus mustahil, karena fakta menunjukkan jarang sekali kita bisa bebas seutuhnya dari pelbagai tekanan dan sangat sulit untuk membuat putusan yang sungguh bebas. $^{1,6}$

Bila pasien itu bebas, berarti ia juga berhak untuk menolak pengobatan. Situasi ini bisa menimbulkan konflik antara prinsip autonomi dan prinsip beneficentia. Dalam hal ini perlu dipertimbangkan kompetensi walaupun dapat juga terjadi bahwa kompetensi dikurangi karena ketakutan atau keadaan emosi pasien. Dalam hal ini dokter jangan terlalu cepat menganggap pasien tidak kompeten. Sejauh mana kompetensi pasien untuk mengambil keputusan tergantung pada pemahamannya akan informasi dan komunikasi antara pasien dan dokter. Kunci hubungan yang paling efektif antara pasien dan dokter adalah komunikasi yang baik. $^{1,6,10}$

\section{Penolakan Tindakan Medis (Informed refusal)}

Selain memberi persetujuan, pasien juga berhak menolak tindakan medis tertentu sebagai individu yang kompeten, informed, dan bebas. Atas penolakan itu dapat diajukan pertanyaan kritis, "apakah ada implikasi dan batas-batas dari prinsip otonomi"? Dalam The Patient's Bill of Rights dikatakan: "The patient has the right to refuse treatment to the extent permitted by law, and to be informed of the medical consequences of his actions". Penolakan itu dibuat atas dasar hak untuk menentukan diri sendiri. Masalah akan muncul bila pasien menolak tindakan medis tertentu yang justru sangat penting untuk mempertahankan hidupnya. Sebagai contoh, penolakan transfusi darah, amputasi, atau meanjutkan dialisis ginjal. Begitu pula muncul masalah sehubungan dengan penolakan pihak kedua (keluarga misalnya) dalam kasus anak-anak dan pasien-pasien yang tidak kompeten. Pengadilan misalnya tidak dapat memaksakan persetujuan dari pasien kompeten yang menolak diberi transfusi darah atas dasar keyakinan religiusnya (Saksi Yehova). Tetapi pihak pengadilan tidak dapat menerima penolakan transfusi darah orang tua Saksi Yehova atas nama anak mereka yang baru lahir yang justru tak kompeten. ${ }^{1}$

Penolakan pengobatan dalam situasi perpanjangan hidup dengan sarana artifisial, tidak dapat dikatakan sebagai upaya "bunuh diri". Penolakan tindakan medis yang tidak bermanfaat tidak dapat disamakan dengan bunuh diri. Lebih tepat 
penolakan itu dipandang sebagai penerimaan kondisi manusiawi yang terbatas atau keinginan untuk menghindari penggunaan teknologi medis mutakhir yang tak seimbang dengan hasil positif yang hendak dicapai, atau keinginan pasien untuk tidak memberi beban berat bagi keluarga atau masyarakat. Bila seseorang menderita penyakit terminal dan membiarkan kematian terjadi atas dirinya, hal ini tidak dapat dikatakan sebagai bunuh diri. Tetapi bila seorang pasien dengan penyakit terminal mengakhiri hidupnya secara aktif, misalnya dengan menembakkan pistol pada dirinya, maka umumnya kita menyebut tindakan itu sebagai "bunuh diri". Banyak orang mengakhiri hidup mereka dengan bunuh diri secara berencana. Namun tidak semua tindakan itu dilakukan dengan sikap otonom. Pada umumnya kematian dianggap "bunuh diri" bila muncul dari suatu usaha sendiri (self-destruction), dan bukan disebabkan oleh tindakan orang lain. Disebut Tindakan "bunuh diri" bila seseorang mengakhiri hidupnya sendiri sebelum waktunya. ${ }^{1,6}$

\section{Informed Consent dan hukum yuridis}

Dalam praktek kedokteran, prinsip informed consent ini, dan standar praktek profesi medis (the professional practice standard) berkaitan dengan malpraktek. Valentin $\mathrm{V}$ mendefinisikan malpraktek sebagai "Kelalaian dari seorang dokter atau perawat untuk mempergunakan tingkat kepandaian dan ilmu pengetahuan dalam mengobati dan merawat pasien yang lazim dipergunakan terhadap pasien atau orang yang terluka menurut ukuran di lingkungan yang sama". Dokter yang karena profesionalismenya dan terdorong untuk berbuat yang terbaik bagi pasiennya (prinsip beneficentia) tanpa informed consent segera bertindak dan ternyata menimbulkan kerugian bagi pasien, maka dokter harus bertanggung jawab atas dugaan umum telah terjadi malpraktek. Dalam kasus dugaan malpraktek, unsur yang umumnya diperiksa adalah informed consent dan standar praktek profesi medis yang dipakai dokter.

Informed consent sangat dibutuhkan dalam tindakan medis terutama yang dikategorikan sebagai extraordinary means, karena memiliki dimensi hukumnya. Dalam Kitab Undang-Undang Hukum Pidana terdapat beberapa pasal yang mengatur penghapusan hukuman terhadap pelakupelaku pidana seperti pasal 44 (sakit jiwa), pasal 48 (unsur paksaan), pasal 49 (membela diri karena terpaksa), pasal 50 (melaksanakan ketentuan undang-undang) dan pasal 51 ( melaksanakan perintah jabatan sah). Hukum yang berlaku umum ini tetap berlaku juga bagi profesi kedokteran. Namun masih terdapat faktorfakor khusus yang berlaku untuk profesi medis yang tidak dijumpai dalam hukum yang berlaku umum, seperti :

1) Risk of treatment : resiko inheren, reaksi alergi, komplikasi dalam tubuh pasien. Dalam tindakan medis tertentu (operasi, pemberian obat) selalu ada resiko melekat (inherent risk of treatment). Dokter sudah bertindak hati-hati dan memenuhi standr praktek profesi medis dan informed consent, namun efek samping (risiko) tetap terjadi. Dalam situasi ini dokter tidak dipersalahkan. Sama halnya dengan bila terjadi reaksi alergi yang tidak dapat diperkirakan sebelumnya.

2) Medical accident or misadventure (kecelakaan tindakan medis) yang sama sekali tidak dapat diduga dan bukan merupakan tujuan tindakan.

3) Non-negligent error of judgment (kekeliruan penilaian klinik). Dalam situasi ini selalu berlaku adagium dalam ilmu hukum yaitu errare humanum est (Latin), artinya kesalahan itu manusia- 
wi. Dan doktrin lain yang berlaku juga dalam ilmu kedokteran yaitu respectable minority rule, artinya seorang dokter tidak dianggap melakukan kelalaian jika ia memilih salah satu (dari sekian banyak) metode/cara pengobatan yang lazim/diakui dalam dunia kedokteran.

4) Volenti non fit inura. Doktrin ini berdasarkan pandangan bahwa bila seseorang telah mengetahui bahwa ada resiko dan secara suka rela bersedia menanggung resiko tersebut, jika kemudian resiko itu benar terjadi, ia tidak lagi dapat menuntut (he who willingly undertakes a risk cannot afterwards complains). Contoh di bidang olah raga yang tergolong keras seperti tinju, bela diri, terjun payung, dan sebagainya. Dalam dunia kedokteran seperti beberapa operasi yang mengandung resiko yang sangat tinggi yaitu cangkok ginjal dari donor hidup. Resiko ini melekat pada donor dan resipiens, dan bila resiko ini terjadi dokter tidak mungkin dituntut.

5) Contributory negligence, yaitu sikap tindak yang tidak wajar dari pihak pasien, yang mengakibatkan kerugian atau cidera pada dirinya, tanpa memandang apakah pada pihak dokter terdapat pula kelalaian atau tidak. Doktrin ini juga tidak memandang apakah sikap tindak pasien itu sengaja atau tidak, dan ini menjadi dasar peniadaan/penghapusan hukuman pada pihak dokter. Misalnya pasien berkeras pulang ke rumah setelah operasi padahal belum diizinkan oleh dokter. Kelalaian dari pihak pasien seberapa kecilpun, dapat menjadi alasan penghapusan/peniadaan hukuman pada pihak dokter.

Jelaslah bahwa syarat utama pemberlakuan doktrin-doktrin ini ialah bahwa dokter memenuhi standar praktek profesi medis dan informed consent. Menurut Chin Keow V (1967) ukuran standar praktek profesi medis adalah dari orang yang berpendidikan dalam profesinya yang biasa (wajar), dan bukan ukuran dari seorang ahli yang terpandai. Dinyatakan cukup bila ia telah menjalankan ilmunya menurut orang berpendidikan yang setingkat dan wajar. Dengan kata lain, mengikuti standar medik yang umum dipergunakan oleh teman sejawat lainnya di dalam keadaan yang sama. Apabila kedua syarat ini tidak dipenuhi oleh dokter maka dapat dikatakan bahwa dokter telah melakukan tindak kelalaian atau kesalahan medis. Untuk itulah diperlukan suatu proses peradilan karena hakim akan memutuskan apakah suatu peniadaan/ penghapusan hukuman dapat diberlakukan atau tidak. Dan yang memberi penilaian ialah profesi yang bersangkutan. Untuk itu dibutuhkan saksi ahli agar tujuan memenuhi rasa keadilan dapat dicapai. ${ }^{8}$

\section{Informed consent dalam praktek medis}

Dewasa ini informed consent telah diterima sebagai prinsip dasar dalam pelayanan kesehatan, walaupun dengan konteks yang sering berbeda. Sebagai contoh, prinsip yang berlaku di Amerika Serikat yaitu setiap manusia adalah otonom, sehingga ia sendiri harus diikutsertakan dalam semua tindakan yang menyangkut dirinya. Dengan demikian paternalisme yang memperlakukan seseorang dengan melewati kebebasannya ditolak dengan tegas. Informed consent mengandalkan otonomi dan individualitas manusia. Berbeda halnya dengan suasana kebudayaan di Indonesia (dan Asia pada umumnya) yang lebih menekankan sosialitasnya, yaitu keterikatan seseorang dengan keluarga dan masyarakat di sekitarnya. ${ }^{3}$

Di Indonesia bila diperlukan tindakan operasi atau tindakan medis lainnya di rumah sakit, maka yang diminta menandatangani surat izin adalah keluarga, dan bukan pasien itu sendiri. Juga di bidang proses pengobatan dan prospek penyembuhan, para dokter umumnya berkomunika- 
si dengan keluarga, dan jarang langsung dengan pasien sendiri. Keadaan itu diterima oleh pasien maupun keluarga sebagai hal yang biasa. Di sini tampak jelas pengaruh faktor budaya. Selama tidak ada keberatan, dokter melanjutkan kebiasaan untuk berkomunikasi dengan keluarga saja, dan informed consent tidak perlu dipaksakan. Keadaan akan menjadi berbeda bila pasien menuntut haknya dan mengemukakan keinginannya agar dokter langsung memberi informasi kepadanya. $^{3}$

Ketergantungan pasien pada dokter dan keluarga termasuk tradisi budaya Asia pada umumnya. Berkaitan dengan hal ini, Jepang merupakan contoh yang sangat menarik. Jepang merupakan negara Asia yang paling maju dalam bidang teknologi serta pelayanan medis, tetapi di situ juga nilainilai tradisional masih tetap dipertahankan dengan kuat. Tak dapat disangkal kenyataan bahwa kini di Jepang pun sedang berlangsung perubahan kultural. Otonomi pasien dan hak-hak pasien semakin mendapat perhatian. Rihito Kimura, staf Kennedy Institute of Ethics di Washington dan menjabat direktur Asia Bioethics Program di sana menulis mengenai perkembangan masyarakat di Jepang. Dalam konferensi nasional pertama tentang hakhak pasien yang berlangsung di Tokyo Desember 1984, ditekankan hak-hak pasien untuk mengambil keputusan berdasarkan nilai-nilai moralnya sendiri. Namun demikian, otonomi yang semata-mata individualistis - salah satu prinsip fundamental dalam bioetika Barat - merupakan pengertian yang tidak cocok untuk diterapkan pada pola sosio-budaya Jepang. Hal ini disebabkan terutama karena tradisi pengambilan keputusan oleh keluarga dalam konteks pelayanan medis yang paternalistis. ${ }^{3}$

Perkembangan yang sama mulai terlihat juga dalam masyarakat Indonesia. Hal ini tampak dalam dua pernyataan yang dikeluarkan oleh Pengurus Besar Ikatan
Dokter Indonesia (IDI). Yang pertama tentang informed consent dan kedua tentang medical record (rekam medis). Dalam pernyataan pertama dikatakan bahwa dokter tidak berhak melakukan tindakan medis yang bertentangan dengan kemauan pasien, walaupun untuk kepentingan pasien itu sendiri. Setiap tindakan medis yang mengandung risiko cukup besar hanya dapat dilakukan setelah adanya persetujuan tertulis yang ditandatangani oleh pasien. Sebelumnya pasien harus diberikan informasi yang adekuat tentang perlunya tindakan medis serta risiko yang berkaitan dengannya. Batas usia pasien yang bisa menandatangani sendiri persetujuan tindakan medis seperti operasi adalah 18 tahun. Bila usianya kurang dari 18 tahun harus mendapat persetujuan orang tua atau wali. Dalam pernyataan kedua ditegaskan bahwa rekam medis harus dibuat dengan teliti. Pasien berhak meminta dan memiliki semua catatan medis tentang dirinya, sedangkan dokter serta rumah sakit bertanggungjawab untuk menyimpannya. ${ }^{3}$

Bila dilaksanakan dengan konsekuen kedua pernyataan IDI ini, maka derajat etis pelayanan kesehatan di Indonesia tidak akan kalah dengan negara-negara maju dalam bidang hak-hak pasien. Kenyataannya sampai sekarang praktek masih berbeda jauh dengan yang dianjurkan IDI itu, terutama karena faktor budaya. Terlebih lagi pernyataan IDI sampai saat ini belum cukup dijadikan dasar hukum untuk dunia kedokteran. Akhirnya dapat ditambahkan bahwa walaupun di tahun-tahun terakhir terdapat banyak perhatian dalam media massa untuk kasus-kasus malpraktek di bidang kedokteran, hal itu tidak perlu ditafsirkan sebagai tanda merosotnya moral para dokter. (sulit sekali membuktikan hal ini secara empiris). Gejala itu lebih baik diinterpretasikan sebagai tanda yang menunjukkan bahwa masyarakat (khususnya pasien) menjadi lebih sadar akan haknya, 
jadi merupakan tanda terjadinya suatu perubahan sosio-budaya. ${ }^{3}$

Akhirnya perlu ditegaskan bahwa dasar pemenuhan informed consent dan standar praktek profesi medis adalah landasan etika-moral dan bukan landasan hukum yuridis. Bila ada dugaan bahwa tindakan medis tertentu telah melanggar prinsip-prinsip etika moral yang mengakibatkan kerugian bagi pasien, yakni tidak memenuhi prinsip informed consent, berada di bawah standar praktek profesi medis, melakukan kelalaian (negligence) atau kesalahan, maka dapat dikenakan sanksi yuridis. Penghapusan akan diberikan bila ternyata terbukti tidak melakukan kelalaian atau kesalahan.

\section{KESIMPULAN}

1. Informed consent mutlak diperoleh terutama dalam tindakan medis yang dikategorikan sebagai extraordinary means, sebagai ungkapan hormat akan otonomi dan integritas pribadi pasien.

2. Informed consent diperoleh dari pasien sendiri, tetapi bila pasien tidak kompeten, maka dapat diperoleh dari keluarga atau wali sah yang mampu memberikan persetujuan rasional. Jika keluarga dan/atau wali hadir namun tidak kompeten juga, maka tenaga medis dapat memutuskan sendiri untuk bertindak sesuai kondisi pasien demi kepentingan terbaik pasien (prinsip beneficentia).

3. Berdasarkan informasi yang diberikan tenaga medis, pasien dan atau keluarga dapat saja menolak memberikan persetujuan atas tindakan medis tertentu (informed refusal). Menghadapi hal sedemikian tenaga medis harus bersikap rasional sebagai seorang medikus sekaligus etikus-moralis, dengan mempertimbangkan kompetensi penolakan tersebut dan kondisi pasien yakni entah tindakan medis masih bermanfaat baginya ataukah sudah menjadi sia-sia belaka.

4. Informed consent tidak dibutuhkan dalam kasus darurat (emergency) atau kritis di mana tindakan medis harus segera diambil demi keselamatan pasien. Tindakan ini diambil atas dasar prinsip beneficentia.

5. Informed consent dan the professional practice standard sangat penting diperhatikan, karena setiap kelalaian atau kesalahan tindakan medis akan membawa konsekuensi hukum yuridis.

6. Dalam pelayanan kesehatan di Indonesia untuk dilakukannya suatu operasi misalnya, informasi disampaikan kepada keluarga dan keluarga yang menandatangani surat persetujuan, bukan oleh pasien sendiri walaupun ia kompeten, maka hal ini hanya merupakan perbedaan budaya saja yang umum berlaku di Asia.

\section{SARAN}

Pemahaman mengenai informed consent perlu ditanamkan kepada para dokter, tenaga medis maupun mahasiswa kedokteran sedini mungkin untuk terciptanya komunikasi yang baik dengan pasien, keluarga, dan masyarakat. Sangat diharapkan bahwa hal ini dapat mengurangi atau bahkan mencegah terjadinya malpraktek beserta segala konsekwensinya.

\section{DAFTAR PUSTAKA}

1. Beauchamp T/J. Childres. Principles of Biomedical Ethics, New York/Oxford: Oxford University Press, 1983; p. 59102, 222-225.

2. Beauchamp T/J. Childres. Philosophical Ethics, An Introduction to Moral Philosophy, New York/ Oxford: Oxford University Press, 1982; p. 117-130.

3. Bertens K. Mencari Tema-Tema Bioetika dalam Konteks Indonesia, dalam Bioetika, Refleksi Atas Masalah Etika 
Biomedis, Seri Filsafat Atmajaya: 12. Jakarta: PT. Gramedia, 1990; p. 84-88.

4. Duncan AS, Dunstan GR. Welbourn RB, editors. Dictionary of Medical Ethics (2nd ed). London: Darton, Longman \& Todd, 1981; p.113-250.

5. Gerald K. Medico-Moral Problems. New York: The Catholic Association of the United States and Canada, 1959; p. 128-129.

6. Griese Orville N. Catholic Identity in Health Care: Principles and Practice, Massachusetts: The Pope John Center,
186, Forbes Road, Braintree, 02184, USA, 1987; p. 155-163

7. Gunawan J. Malpraktek medik. Jakarta: Balai Penerbit FKUI, 1983; p. 3.

8. Gunawan J. Kelalaian medik (Medical negligence). Jakarta: FKUI, 1994; p. 85-93.

9. Heuken SJ, et al. Ensiklopedi Etika Medis. Jakarta: Yayasan CLC, 1979; p. 298300.

10.Shannon Thomas A. Pengantar Bioetika, Seri Filsafat Atmajaya: 16,. Jakarta: Gramedia, 1995; p. 20-33. 